\title{
MOPPETS ON THE MARKET: THE PROBLEM OF UNREGULATED ADOPTIONS
}

THE market for babies is a sellers' market. As a result, a few individuals make money by selling babies as they would sell goods. Contrary to popular impression, however, "black market" placements-independent ${ }^{1}$ adoptive placements in which a third party makes a profit-are not common. By far the greater number of adoptions are the product of independent placements arranged without profit by well-meaning parents, friends, relatives, doctors, and lawyers. ${ }^{2}$ Only in about one-fourth of the cases are placements

1. An "independent" placement is one made without the aid of an authorized childwelfare agency. Authorized agencies include state welfare departments and private agencies which they license and supervise. The welfare department usually has authority to license private agencies to engage in child-placing work See, c.g., Afrcr. Ans. Stat. $\$ 25.358$ (3) (Henderson, Supp. 1949) ; S.D. Laws 1939, c. 168, \$3. Only a few states, however, require that all adoptive placements be made through these authorized agencies. See pages $731-4$ infra.

2. This conclusion is based upon information received in response to a questionnaire sent to the welfare departments of the various states. Replies were received from thirtyfive states and the District of Columbia. As to the extent of "black market" trading in babies, the following statements are typical. "[W]e do not believe there is much of this activity in Texas. . . . What we have seen referred to as the 'grey market' is much more prevalent in this State. It involves placements by physicians, lawyers, ministers, midwives, who are often well-meaning, but who cannot, of course, offer the protcetion of agency services." Communication to the Yale Law Jourawal from Mir. John H. Winters, Executive Director, Texas Department of Public Welfare, dated January 3, 1950, in Yale Law Library.

"For the most part, intermediaries in independent placements are physicians, nurses, lawyers and friends of the mother or friends of the petitioners who participate sometimes directly and other times indirectly in the placements. It is our belief that for the most part these intermediaries are persons who have known of the petitioners' desire for a child, or know of the mother's interest in relinquishing or releasing a child for adoption, but we do not consider that they are actively engaged in child placing from a commercial standpoint." Communication to the Yale Law Jouranal from Miss Lo3 Howard, Administrator, Oregon Public Welfare Commission, dated January 18, 1950, in Yale Law Library.

It appears that the bulk of independent placements are made by parents and physicians. An analysis of 2,587 independent adoptions which were approved by the California welfare department in 1948, for example, revealed that 43.8 percent of the placements had been made by parents and 25.6 percent had been made by physicians. Communication to the Yale Law Journal from Miss Míyrtle Williams, Director, California Department of Social Welfare, dated November 30, 1949, in Yale Law Library.

Although "black market" placements are not frequent, it is a common practice in independent placements for adoptive parents to pay the doctor's fee and the hospital expenses of the natural mother. A study of 992 children placed independently with non-relatives in Florida in 1947-S disclosed that in at least 45 percent of the cases both the doctor's fee and the hospital costs had been paid by the adoptive parents. WArD, Analysis of Adoptions IN FloRrda 1943-49, p. 10 (mimeographed, 1949). The situation in other states is similar. Louisiana, for example, reports that "there are a very large 
made by authorized child-welfare agencies, which are best equipped to protect the interests of all by seeing that the right child gets in the right home. ${ }^{3}$

When adoptions are the product of independent placements, the blind frequently lead the blind. Good intentions are no substitute for traincd and experienced personnel. The interests of the child, as well as those of the natural and adoptive parents, may be lost and unprotected in a humanitarian mist. The problem is becoming acute, for adoption is increasing by leaps and bounds. Adoption petitions were filed for approximately 50,000 children in 1944, a three-fold increase over 1934. ${ }^{4}$ And recent figures indicate another 40 to 50 percent increase in the last five years. ${ }^{5}$

Most of these children are adopted at an age when they are far too young to look after their own interests. A recent Children's Bureau survey indicated that at the time of the filing of the adoption petition, 62 percent were under six, 26 percent were between six and fourteen, and 12 percent were between fourteen and twenty-one. ${ }^{6}$ This extreme youth also makes it

number of cases which although not strictly 'black market' involve the payment of support to the girl during the period of her pregnancy or confinement as well as various presents under the guise of providing the girl with an adequate wardrobe, helping her find a job, giving her rail fare back to her home town, etc." Communication to the YaLs LAw Journal from Mr. Lawrence E. Higgins, Commissioner, Louisiana Department of Public Welfare, dated November 9, 1949, in Yale Law Library.

3. A Children's Bureau (Federal Security Agency) study of 9,000 children for whom adoption petitions had been filed in fifteen states in 1944 disclosed that slightly more than a quarter had been placed in the adoptive home by an authorized agency; another quarter had been placed independently with unrelated persons; and approximately a half were being adopted, without the aid of an agency, by stepparents and other relatives. Zarcisky, Children Acquire New Parents, 10 CHID 142, 143 (1946). The proportion of acloptive placements made by authorized agencies varies substantially from state to state, however. Thus Maine reports that of the total number of adoptions made in that state in 1948, only 9 percent involved placements by authorized agencies, whereas in Louisiana authorized agencies handled 48 percent. Communications to the YALE LAW JourNaL from Miss Lena Parrott, Director of Child Welfare, Maine Department of Health and Welfare, dated November 14, 1949, and from Mr. Lawrence E. Higgins, Commissioner, Louisiana Department of Public Welfare, dated November 9, 1949, both in Yale Law Library.

4. In 1944 twenty-two states reported a total of more than 16,000 children for whom adoption petitions had been filed. On the basis of this figure the Children's Burcau estimated that in that year petitions had been filed for approximately 50,000 children throughout the country. Zarefsky, supra note 3, at 142. In the six states for which comparable statistics were available, the number of children for whom petitions were filed in 1944 was more than three times as great as in 1934. Ibid.

5. The Children's Bureau is at present collecting data on the number of petitions filed in 1948. Preliminary examination of some of the reports where comparable data are available for 1944 indicates that adoption petitions have increased between 40 and 50 percent since that time. Communication to the YaLe LAw JourNal from Miss I. Evelyn Smith, Consultant on Foster Care, Social Service Division, Children's Bureau, dated November 22, 1949, in Yale Law Library.

6. Zarefsky, supra note 3 , at 143. This information was available for 8,764 of the 9,000 children for whom adoption petitions were filed in fifteen states in 1944. Almost 
inordinately difficult for potential adoptive parents or any untrained layman to make an intelligent decision, to foresee future problems latent at the time of adoption.

In an effort to protect all parties, most states have passed laws providing for an increased administrative and judicial supervision over adoption generally. These laws vary considerably in effectiveness and in strictness of enforcement, but the best reflect the procedure of authorized adoption agencies. Their procedure, while not wholly standardized, eliminates much of the hazardous guesswork inherent in casual independent placements, and substitutes an informed professional judgment which may offer the best hope for family happiness.

\section{The Practice of Authorized Adoption Agencies}

Authorized adoption agencies are of three general types: state welfare departments, private agencies engaged solely in adoption work, and private agencies whose adoption activities are only one part of a general childwelfare program. In many states the welfare department's adoption service merely supplements private facilities, ${ }^{7}$ but in one state that department is the sole agency making adoptive placements. ${ }^{8} \mathrm{~A}$ few private agencies in large cities are adoption agencies exclusively, providing care only for children made available for adoption. ${ }^{9}$ But the great majority of private agencies placing children for adoption are general child-welfare agencies, whose purpose is to provide all types of care for dependent, neglected, or delinquent children.

Many of the children under the supervision of a general welfare agency are not available for adoption. Some are away from their families only temporarily. ${ }^{10}$ Other children, though likely to remain under the agency's care for a longer period, are unavailable for adoption because their parents

half of the children were being adopted by stepparents and other relatives, and such children usually are older than others being adopted. Therefore the proportion of young children being adopted by non-relatives was even greater than the figures indieate. Ibid.

7. E.g., Maine, Nebraska, Washington. In a few states placements are also made by county adoption agencies. California, for example, amended its adoption law in 1947 to authorize the licensing of county adoption agencies by the state welfare department. CAL. CrVIL CODE $\$ 225 m$ (Deering, 1949). The county adoption agencies are reimbursed by the state for their entire administrative costs and for a portion of the costs of caring for children relinquished to them. Communication to the YALE LAW Jour:iar from Mfiss Myrtle Williams, Director, California Department of Social Welfare, dated November 30, 1949, in Yale Law Library.

8. Arkansas. Communication to the $Y_{\text {ALE }}$ LAW Journal from Mrrs. Henry Bethell, Commissioner, Arkansas Department of Public Welfare, dated December 27, 1949, in Yale Law Library.

9. Wilson, What the Layman Does Not Know About Adoption, 26 Camd Wenfare League of AMrerica Bulietin 13, 14 (June 1947).

10. In a typical instance the child's mother is being divorced and remarried, after which the child will'return to her. See Lockrmag, Adoptrng a Crmo 28 (pamphlet ed, 1948). 
have neither abandoned them nor consented to their adoption." Some children are not adoptable because of serious mental and physical defects. For all these children who cannot be placed in adoptive homes, the agency must provide some alternative form of care, either in private families or in an institution. Many of them are placed in boarding homes, private homes in which the agency pays the cost of the child's basic maintenance.

The children who are available for adoption come under the supervision of an authorized agency in a variety of ways. Some are orphans and foundlings. Others have been removed from their homes and placed under agency guardianship by a court order because they were neglected or mistreated by their parents. But a far greater number of children are voluntarily surrendered to the agency, most often by unwed mothers. Illegitimate children account for about 60 percent of all children adopted, ${ }^{12}$ and if adoptions by stepparents and other relatives are excluded, this figure runs even higher. Thus, one of the adoption agency's main responsibilities is to provide prompt, sympathetic, and skillful service for the unmarried mother. ${ }^{13}$ If she is undecided about surrendering her child for adoption, the agency explores with her the alternatives, including temporary placement in a boarding home. Often a mother who has surrendered a child immediately after its birth later finds that she is in a position to care for the child. A reputable agency accepts a surrender only after the mother herself has decided that adoption is the best plan. But once a child is deemed available for adoption, four procedures are carried out: an investigation of the natural parents, a study of the child, an evaluation of the prospective adoptive parents, and a supervised probationary period.

\section{Investigation of the Natural Parents}

If a child's parents are known-that is, if he is not a foundling - the agency seeks information about his family background. An unmarried mother is asked to disclose confidentially to the agency the name of the child's father, so that the agency can investigate both the maternal and paternal histories. Some agencies regard a child as unsuitable for adoption if his family history discloses pathological conditions which some medical opinion views as hereditary. ${ }^{14}$ But most agencies feel that little is known about what con-

11. Stougaard, Uiwonnd Talk About Adoption, 27 Crild Welfare 17 (November, 1948).

12. The Children's Bureau study of 9,000 children for whom adoption petitions were filed in fifteen states in 1944 revealed that 58 percent of the children were illegitimate. Zarefsky, supra note 3, at 144. An earlier Bureau study of 2,041 adoption petitions filed in nine states in 1934 disclosed that 61 percent were for illegitimate children. Counx, PronLems and Procedures in Adoption 10 (Children's Bureau Publication No. 262, 1941).

13. See Social Workers Look at Adoption, 10 CHun 110 (1946) for an appraisal of agency shortcomings in this respect.

14. See Lippman, Suitability of the Child for Adoption, 7 AMrrican Journal of Orthopsychiatry 270 (1937); Teagarden, Child Psychology for Professionar WORKERS 30-68 (1940). 
ditions are inheritable, and that no child should be excluded from adoption solely on the basis of his assumed hereditary background. ${ }^{15}$ A child whose family history is spotted with feeblemindedness, epilepsy, or psychoses, needs special scrutiny, but his family background is only one of many elements to be taken into account before a final decision is made as to whether he is adoptable. ${ }^{16}$

\section{Study of the Child}

Most agencies place the child in a pre-adoption boarding home for at least three months as soon as he comes under their care. ${ }^{17}$ During this period the agency tries to get as complete a picture of the child as possiblephysically, mentally, and psychologically. ${ }^{18}$ The first step is a thorough medical examination. ${ }^{19} \mathrm{~A}$ child may still be adoptable though suffering from congenital abnormalities, such as blindness or deafness, or from a disease like syphilis, tuberculosis, or diabetes. But the agency must know these medical facts in order to provide immediate treatment. Eventually it may pass the child on to adoptive parents who, fully informed of the child's condition, still wish to adopt him and have the means to provide him with proper medical care.

It is equally important that the agency have an estimate of the child's intelligence, maturity level, and rate of development. For children two years of age and older the Stanford-Binet intelligence test is most commonly used. But many of the children adopted are younger than two, and for them no Stanford-Binet test is available. ${ }^{n}$ Increasing use is being made of the

15. See Clothier, Placing the Child for Adoption, 26 AIENTAL HyGIENe 257, 259-61 (1942); Theis, Case Work in the Process of Adoption in 69 Proczedings of Trre NATTONAL CONFERENCE of Soctal Work 405, 409 (1942); Wolkomir, The Unadoptable Baby Achieves Adoption, 26 Child Welfare League of Aarrerca Bulletm 1 (Feb. 1947).

16. Various studies have explored the relative influence of heredity and environment upon the mental development of adopted children. See, e.g., Freeman, Holzinger, \& Mitchell, The Influence of Entironment on the Intelligence, School Achictement, ard Conduct of Foster Childrent, 27 Nationar Society for the Study of Eddcation YearBOOK 103 (1928); Burks, The Relative Influence of Nature and Nurture uson Mamal Development, $27 \mathrm{id}$. at 219; Leahy, Nature-Nutrture and Intelligence in 17 GestetIC Psychology Monograpes 235 (1937) ; Skodak, Chidren in Foster Hoyres: A Study of Mental Developasent (1939). The results of these and other studies are summarized in Brooks \& Brooks, Adventuring in Adoption 172-9 (1939), and Tengarde:i, op. cil. sipra note 14, at 41-53.

17. Clothier, Adoption Procedure and the Community, 25 Mfental Hyarene 196, 206 (1941). Some agencies have experimented with the practice of transferring the child from his present home to his permanent adoptive home without the use of an interim temporary placement. Oshlag, Direct Placement in Adoption, 27 Jouranal of Socus Casewons 229 (1946).

18. Pendleton, Agency Responsibility in Adoplion, 19 FAsncy 35, 37-8 (1938).

19. See Clothier, Somze Aspects of the Problem of Adoption, 9 Azrerscar Jouranar OF ORTHOPSYCHIATRY 598, 605 (1939).

20. See Terman \& MierriL, Measuring Inteiligence (1937). 
diagnostic tests developed by Gesell and others at the Yale Child Development Clinic for children ranging from four weeks to three years. The Gesell system sets up test situations for each of the four major fields of behaviormotor, adaptive, language, and personal-social.21 A particular child's patterns of behavior in each of these fields is observed and then compared with norms appropriate to his age. ${ }^{22}$ Thus the Gesell system, unlike the Stanford-Binet, is not limited to a single inclusive formula. But regardless of which system is used, the tests are the beginning and not the end of diagnosis. The child's rate of development may change when he is placed in a more favorable environment. ${ }^{23}$ In the last analysis the diagnostician must weigh all the qualifying considerations, including medical history, previous environment, and the performance of the child.

If on the basis of the physical and mental tests a child is found to be unadoptable, he either remains in the agency, is placed in a boarding home, or, if he is definitely feeble-minded, he may be committed to a state institution. A child whose adoptability is uncertain remains under agency care for further testing and observation until a final decision can be made. However, after a child is adjudged adoptable, the sooner he is placed the better. Children adopted at an early age have a far greater chance of normal adjustment. ${ }^{24}$

\section{Evaluation of the Adoptive Parents}

Many agencies have ten times as many applicants as they have children available for adoption..$^{25}$ The agency must first determine, on the basis of interviews and a home study, which of the applicants are fit to be adoptive parents. ${ }^{26}$ Then, from its list of suitable adoptive parents on the one hand and its list of available children on the other, the agency must "match" parents and child.

In the interviews the caseworker explores with the applicants their motives for adoption. The experience of agencies has shown that certain motives on the part of adoptive parents lead to an impossible situation for

21. Gesell \& Amatruda, Developmental Diagnosts 7 (2d ed. 1947).

22. Id. at 111: A separate rating is determined for each of the four fields of behavior. Only when the child's maturity in all fields is at nearly the same level is it deemed permissible to assign an overall maturity level and a general rating. Id. at 114 .

23. Jenkins, Adoption Practices and the Physician, 103 American Medicar Assoctation Journal 403, 405 (1934); Clothier, Placing the Child for Adoption, 26 Mental HyGreNe 257, 262 (1942). And see articles cited in note 16 supra.

24. See Theis, How Foster Children Turn Out 113-118, 163 (1924).

25. Michaels, Casework Considerations in Rejecting the Adoption Application, 28 Journal of Soctal Casework 370 (1947). This figure is corroborated by reports received from various states in response to a questionnaire. See note 2 sitpra.

26. See, generally, Harral, The Foster Parent and the Agency in the Aloption Process in 68 Proceedings of the National Conference of Soctal Work 411 (1941); Brenner, The Selection of Adoptive Parents: $A$ Casezvork Responsibility, 25 Cumb Wefare League of America Bulletin 1 (Dec. 1946). 
the child: the husband or wife thinks that adopting a child is the solution to an unhappy marriage; a couple wants an adopted child merely as a playmate for a child of their own; the family doctor has recommended adoption as a cure for the wife's nervousness. ${ }^{27}$ The caseworker looks for applicants who regard an adopted child as something more than a satisfaction of their own needs, who recognize him as a separate personality with needs of his own. 28

The adoptive parents must have not only the will but the power to give the child a fit home. ${ }^{29}$ This means a state of reasonable health and a life expectancy sufficient to cover the child's growing years. Mental deficiency, drug addiction, epilepsy, alcoholism, or any chronic and incapacitating disease disqualifies an adoptive applicant. Prospective parents must also be capable of providing the child with the necessities of life and with a minimum of educational advantages. Once this basic financial requirement is met, high-income applicants are not necessarily favored over low-income ones. 30

- If the applicant couple is childless, it is important to know whether they are likely to have a child of their own. The subsequent birth of a natural child often places an adopted child in a disadvantageous position, because the need for which a child was adopted has been filled. ${ }^{31}$ Hence many agencies request childless couples to be examined by a gynecologist, and if there is a reasonable possibility of a natural child, their application may be rejected. ${ }^{32}$

Some agencies make a preliminary sifting of applicants on the basis of certain fixed standards. One of the leading agencies in New York City, for example, automatically rules out all women over thirty-five, all men over forty, and all persons who have children of their own. ${ }^{33}$ Some agencies refuse to consider single persons or couples with two or more adopted chil-

27. Clothier, Some Aspects of the Problem of Adoption, 9 Axmericnze Jourrax of Orthopsychlatry 598, 610 (1939) ; Clothier, Placing the Child for Adoption, 26 AferitaL Hygrene 257, 265-6 (1942); Gillean, The Responsibility of Prizatc Child Wclfore Agencies for Adoptions, 17 ChIld Welfare League of Aarerica Bulletri 1 (June 1938).

28. Jenkins, sipra note 23, at 404.

29. Id. at 404-5.

30. For example, two-thirds of the children placed by the Free Synagogue Child Adoption Committee, one of the leading adoption agencies in New York City, are placed in families with annual incomes of less than $\$ 6,000$. Free Syringogue Crmb Arortion Comanttiee, Where A Felier Has a Frennd. See also N.Y. Times, Jan. 10, 1950, p. 37, col. 5 .

31. Clothier, Placing the Child for Adoption, 26 MIENTar. Hygrene 257, 267-8 (1942); Jenkins; supra note 23, at 405; Rathbun, The Adoptize Foster Parcnt, 23 Cumo Werfare LEAGUE of AMtertCA Bulletin 5, 6-7 (Nov. 1944).

32. MrcCormick, The Adopting Paront Sees the Child in Stunies of Crunden 133, 134 (Mleyer ed 1948).

33. Communication to the Yale Law Journal from Miss Roberta Andrews, Assistant Director, Spence-Chapin Adoption Service, New York City, dated Alarch 6, 1950, in Yale Law Library. 
dren. ${ }^{34}$ Most agencies, however, follow what seems to be the more desirable practice of judging each case on its own merits. An unmarried, divorced, or widowed person deserves consideration, even though a family environment is usually more promising. A couple in their forties may on occasion offer the best home for a particular child, despite the fact that preference might normally be given to younger couples.

If an application is accepted, it is followed by a home study. In evaluating a home the caseworker attempts to get a careful diagnostic picture of the applicants as prospective parents. She makes several visits to the home, and also talks with relatives and friends of the family. Her investigation attempts to bring to light any serious personality defects or any evidences of marital incompatibility that might threaten the child's security. ${ }^{86}$ The agency wants couples who are mature and emotionally well adjusted.

Once a home has been approved generally, the "matching" process begins: the agency must decide which children and which parents are best suited to one another. Physical, mental, psychological, and religious factors are taken into consideration. An effort is made to see that the child's features and general appearance do not differ too much from those of his adoptive parents. An agency usually selects adoptive parents of the same race and religious faith as that of the child. Some state statutes make this mandatory, others are merely suggestive. ${ }^{36}$ Insofar as possible, a child of superior in-

34. Michaels, supra note 25, at 370.

35. Clothier, Placing the Child for Adoption, 26 Mental Hygiene 257, 266 (1942).

36. Texas specifically prohibits the adoption of white children by Negroes and of Negro children by whites. Tex. ANn. Crv. Stat. art. 46a, $\$ 8$ (Vernon, 1947). Montana and Louisiana require that the petitioner and the child be of the same race. Mont. REv. Code ANv. \$61-127 (Choate \& Wertz, 1947); LA. Gen. Stat. ANN. \$\$4827, 4839.26 (Dart, 1939). The Nevada adoption statute is inapplicable to any "Mongolian" except in the cases of an adult "Mongolian" seeking to adopt a "Mongolian" child. NEv. Cousr. LAws $\$ 9484$ (Hillyer, 1929). Indiana, Washington, and the District of Columbia, although not prohibiting interracial adoptions, require that the petition include facts as to race. Ind. Stat. AnN. §3-116 (Burns, 1946) ("color" of child); WASH. Rev. Stat. ANN. \$1699-7 (Remington, Supp. 1943) (race of petitioner and child); D.C. CoDE $\S 16-201$ (1940) (race of petitioner and natural parents).

Religious restrictions take a variety of forms. Several states require that a court, when practicable, select adoptive parents of the same religious faith as that of the child or his natural parents. E.g., Ill. ANv. STAT. c. 4, § 4-2 (Smith-Hurd, Supp. 1949) ("whencver possible"); N.Y. Soctal Welfare LaW \$373 ("when practicable"); R.I. Laws 1946, c. 1772 (absolute requirement "if there is a proper or suitable person of the same religious faith or persuasion as that of the child available to whom orders of adoption may be granted"; otherwise "when practicable"). A few states require that information regarding the religion of the prospective adoptive parents and of the child be set forth in the petition. E.g., Iowa CoDE $\S 600.1$ (1946); MD. ANN. Code art. 16, §85F (Flack, Supp. 1947) ; Pa. Stat. Ans. tit. 1, \& 1 (Purdon, Supp. 1948). Some states require that reports submitted to the court by the state welfare department or other agencies include information as to race and religion. E.g., ConN. Gen. Stat. \$ 6867 (1949) (religion); GA. CodE ANN. \$74-411 (Supp. 1947) (race and religion).

These statutory restrictions, especially those forbidding interracial adoptions, raise a 
telligence is placed in a home with intellectual interests and educational advantages. But this is never the main consideration; a child with a high I.Q. may be placed with persons of only average intelligence if the caseworker believes that the child will be well adjusted in his new home and that the applicants will make good adoptive parents.

\section{Probationary Period}

Most agencies require a probationary period of a year in the adoptive home before the adoption is legally consummated. The purpose is twofold: to help adoptive parents integrate the child into their family life, and to make certain that the child is developing normally. During this period an important task of the caseworker is to help adoptive parents clarify their own thinking about what explanation of adoption they will give to the child. ${ }^{37}$ All agencies insist that the child be told of his adoption. ${ }^{89}$ Practice varies widely, however, as to how much information about the child's background should be given to adoptive parents, and through them, to the child himself. ${ }^{33}$ Some agencies tell the parents as little as possible, particularly material of a negative nature. Others believe that adoptive parents should be told everything they wish to know except the names of the child's natural parents. ${ }^{40}$ But all agree that the adoptive parents should at least have full knowledge of the child's medical history, and of any pathological condition in his family history which may be inheritable. ${ }^{41}$

Throughout the probationary period the caseworker maintains contact with the home and observes the success of the placement. ${ }^{42}$ If at the end of a fair trial the child is not making a reasonably satisfactory adjustment,

serious constitutional question under the "equal protection" clause of the Fourteenth Amendment. Cf. Perez v. Lippold, 32 Cal. 2d 711, 198 P.2d 17 (1948), 58 YALE L. J. 472 (1949) (California anti-miscegenation statute held unconstitutional as violative of "cqual protection" clause). Even those statutes which are merely suggestive raise the possibility that an unconstitutional criterion is sought to be applied.

37. See Rautman, Adoptive Parents Necd Help, Too, 33 Mrearral Hygrene 424 (1949).

38. Eppich \& Jenkins, Telling Adopted Children in Studres of Camones 96 (Mfeyer ed. 1948).

39. Because of the confidential nature of adoption records, over half the states have provisions protecting such records from public inspection. Berkley \& Colby, Problcms in Safeguarding Adoptionis, 23 Journal of Pediatrics 344, 349 (1943). Access is usually limited to "parties in interest" or "parties to the action." Ibid. The Children's Bureau recommends that all adoption records, including those of state velfare departments and of any other agencies participating in the adoption, be made available only on court order. Essentzals of Adoption Lav and Procedure 24 (Children's Bureau Publication No. 331, 1949). As to changes in birth records following adoption, see Fereral Secunutr Acencr, The Confidential Nature of Birth Records 6-S (1949); Colby, Progress in Adoplion Legislation, 16 Sociat. Service Review 64, 72-3 (1942); Huffman, A First Protcction for the Child Born out of Wedlock, 11 Cand 34 (1946).

40. Lippman, supra note 14, at 273.

41. Clothier, Placing the Child for Adoption, 26 Mfental Hygrene 257, 271 (1942).

42. Jenkins, supra note 23 , at 407 . 
the placement is terminated. A doubtful placement may require that the probationary period be extended. If a reexamination of the child produces favorable results and the placement is judged to be successful, the agency gives its consent to the adoption.

\section{The Regulatory Problem}

When a child is placed independently, the safeguards of agency practice are lacking and the risks of adoption are increased many-fold. Since the identities of natural and adoptive parents are seldom concealed from one another, adoptive parents are frequently harassed by a mother who has changed her mind and wants her child back. Or the child may be mentally deficient. This danger is particularly acute in the case of independent placements with non-relatives, often made when the child is less than a month old, because feeblemindedness can rarely be detected under the age of three months. Furthermore, no systematic effort is made to study the home before placement or to select the home best suited to the particular child. In short, the natural parents may be high-pressured into hasty and ill-considered decisions to surrender their child, the adoptive parents may enter the arrangement blindly, and throughout the placement process the child himself is a helpless pawn. ${ }^{43}$

In order to minimize these risks, regulatory legislation should extend to all adoptions the careful procedures of the more competent authorized agencies. The statutes should protect three sets of interests. They should protect the child from separation from natural parents who might give him a good home if sufficient help were available to them, and from adoption by persons unfit to rear a child. They should guard the natural parents from hurried decisions to give up their child, made under strain and duress. Finally, they should protect the adoptive parents from assuming responsibility for a child whose mental and physical condition is questionable, and from interference by the natural parents after the child has been satisfactorily established in his new home.

Existing laws are of two types: adoption statutes proper, which govern

43. The need for adequate safeguards in adoptive placements was demonstrated in a. study conducted in 1945 by Dr. Catherine S. Amatruda of the Yale Child Development Clinic. Dr. Amatruda undertook to analyze the results of 100 independent placements and 100 agency placements. Her standards were modest. A child was regarded as a good adoption risk unless it was mentally retarded or had serious personality defects. A family was regarded as suitable unless the investigation disclosed a highly unstable marriage, serious psychiatric difficulties, alcoholism, prostitution, wife beating, or drug addiction. Of the hundred independent placements, only 46 were satisfactory; 26 were questionable at best; and 28 were definitely undesirable. The hundred agency placements, on the other hand, had brought about a satisfactory situation in 76 instances; a questionable situation in 16; and an undesirable situation in only 8. Yale Child Development Chrict, REport of Current Adoption Practices in Connecticut-Independent and Agency Placennent (mimeographed, 1949). See also Colby, Prolection of Children in Adaption in 65 Proceedings of the National Conference of Social Wonk 146, 155-6 (1939). 
the court proceeding; and placement statutes, which regulate the placing of children in homes in contemplation of adoption. In most states the pattern of regulation under these statutes is seriously deficient.

\section{Adoptron Statutes}

Adoption was unknown to the common law and was not authorized by statute in Great Britain until 1926. ${ }^{14}$ The earliest adoption statutes in the United States permitted adoption by means of a deed, without court proceedings of any kind. ${ }^{45}$ A Massachusetts statute of $1851^{40}$ was the first to require a formal judicial proceeding. ${ }^{47}$ Adoption by deed persisted in other states for many years thereafter, but such provisions have gradually been repealed, and today every state requires that adoption be by judicial proceeding..$^{48}$

\section{Jurisdiction and Venue}

Since most adoptions are of minor children, jurisdiction of adoption proceedings is best vested in a court accustomed to handling children's cases. But this is not what the law of some states provides. In Utah, for example, although juvenile courts have had forty-five years' experience handling children's cases, adoption remains in the hands of the district courts." In New York, three sets of courts-county, surrogate's, and children'spreside over adoptions. ${ }^{59}$ Children's courts have jurisdiction over an adop-

44. 2 AbBott, The Chind and the State 164 (1938). The original British statute, $16 \& 17$ GEo. 5, c. 29 (1926), was followed by the Adoption of Children (Regulation) Act, 1939, 2 \& 3 GEo. 6, c. 27, providing for the registration of adoption socicties. Because of the war, the operation of the latter statute was suspended until June, 1943. See New Adoption Regulations in England, 17 Soctat SeRvice Review 369 (1943) ; Adoption Problems in Great Britain, 24 CeILD WeIfare League of Aarerics Buldetrs 10 (April 1945).

On the history of adoption generally, see 2 ABBoTT, op. cit. supra, at 164-228; Brooks \& Broors, op. cit. supra note 16, at 93-110; Gallagher, The Adopted Cand 19-28 (1936) ; Peck, Adoption Laws in the United States 1-2 (Children's Bureau Publication No. 148, 1925) ; Brosnan, The Law of Adoption, 22 Cor. L. REv. 332 (1922).

45. Oler, Construction of Private Instruments Where Adopted Children Are Concerned: I, 43 MrCH. L. REv. $705 \mathrm{n} .1$ (1945).

46. Miass. Acts \& Resolves 1851, c. 324.

47. Oler, stipra note 45, at 705 n.1; Kuhlmann, Interstate Successions by and from the Adopted Child, 28 WASH. U. L. Q. 221, 222-3 (1943).

48. Texas was the last state to enact this requirement. Until 1931 a person could legally adopt a child in that state by filing with the county clerk a written statement of adoption and, if the natural parents were living, a written transfer of parental authority. Tex. Rev. Civ. Stat. arts. 42, 44 (1925). See Note, 18 Tex. L. Rev. 523 (1940). Despite a 1931 statute requiring that all adoptions be by judicial proceeding, TEx. Arr. Crw. Srat. art. 46a (Vernon, 1947), adoption by deed continued to be widespread for several years thereafter. WoOlford, THE AdAInistration of Adoptions under TExas LAws 1936, p. 20 (1938).

49. UTAH CODE ANN. $\S 14-4-7$ (1943). The Utah juvenile courts were created in 1905. See UTaH Cosr. Laws $\$ 720 x$ (1907).

50. N.Y. Domestic Relations LaW \$§ 109, 110. 
tion proceeding only when the child is delinquent, neglected, or dependent, ${ }^{61}$ and as a result they handle a relatively small percentage of all New York adoption cases. ${ }^{52}$

About a third of the states limit venue in adoption actions to the county or district in which the petitioners reside. ${ }^{53}$ Many states permit the action also to be brought where the child resides, especially when the petitioners are non-residents. ${ }^{54}$ Some states further provide that when the child is in the custody of a child-welfare agency, the proceeding may be brought where the agency is located. ${ }^{55}$ These multiple-venue provisions seem unwise. A court must pass judgment on the qualifications of petitioners as prospective parents, and, in some states, must supervise their homeduring a probationary period. ${ }^{56}$ It thus would appear desirable to limit the action to the place where they are known and where their home is located. Only in exceptional cases should they be permitted to bring the action outside the county or district in which they reside, and in no event outside the state of their residence. ${ }^{57}$

\section{Consent}

Every state requires that the consent of certain parties be obtained before an adoption may be approved by the court. ${ }^{58}$ The consent of the child is generally mandatory if he is above a specified age, usually twelve or fourteen."s Most states provide that if the petitioning adult is married, which is the

51. Inforaral Opinions of the Attorney General of NEW York 252 (1944).

52. Of a total of 1,079 adoptions granted in twelve upstate New York counties in 1946, 45 percent were granted by surrogate's courts, 44 percent by county courts, and 11 percent by children's courts. State of New York, Report of the Spectal Committee on Social Welfare and Relite of tee Joint Legislative Committee on INterstate Cooperation (Assemblyman Harold C. Ostertag, chairman) 29 (Legislative Document No. 51, 1948) (hereafter cited as OSterTag REPORT).

53. Leavy, The Law of Adoption Simplified 30-3 (1948). Sec, e.g., Cal. Civ. CODE $\$ 226$ (Deering, 1949) ; Mont. REv. Code ANn. \$61-132 (Choate \& Wertz, 1947).

54. Leavy, op. cit. silpra note 53, at 30-3. See, e.g., Colo. Stat. ANn. c. 4, \&1 (1935) ; Mass. ANN. Laws c. 210, $\$ 1$ (Supp. 1948).

55. E.g., Fla. Stat. ANn. $\$ 72.08$ (Supp. 1948); Md. ANn. Code art. 16, §85B (Flack, Supp. 1947).

56. See pages 730-1 infra.

57. If all states were to limit venue in this manner, one problem might arise: a disproportionately large number of adoptable children in big cities and a corresponding shortage of adoptable children in other areas where the need might be greater. This could be remedied by authorized agencies in metropolitan centers transferring some of their adoptable children to agencies located elsewhere, with the receiving agency reimbursing the transferring agency for expenses already incurred.

58. LEAVY, op. cit. supra note 53 , at 40 .

59. Id. at 40-2. A few states set the age at ten years. E.g., MD. ANr. Code art. 16, § 85G (Flack, Supp. 1947); Mrce. STAT. ANn. § 27.3178(543) (Supp. 1949). Loulisiana and South Carolina are the only states which do not require the consent of the child under any circumstances. 
usual case, his spouse must either consent to the adoption or join in the petition. ${ }^{60}$

Under ordinary circumstances a child may not be adopted without the consent of his natural parents, or, if he is illegitimate, without the consent of his mother. ${ }^{61}$ But every state prescribes certain conditions under which parental consent is not required. Typically consent may be omitted when the parents (a) have abandoned, deserted, or neglected the child; (b) have been deprived of the child's custody by a court of competent jurisdiction; (c) have voluntarily surrendered the child to an authorized child-welfare agency; (d) are habitual drunkards; (e) cannot be found or are unknown; and (f) have been deprived of civil rights or imprisoned for a felony.:2 In many instances, however, there has been no prior judicial determination of whether the parents are guilty of misconduct. As a result, the judge in the adoption proceeding is faced with two questions: whether the natural parents have so conducted themselves that they should be deprived of a child's custody, either temporarily or permanently; and whether the child should be adopted by the petitioners. These questions are quite distinct; the unfitness of the natural parents does not establish the fitness of the petitioners. Yet if the two issues are part of the same proceeding, it is difficult to keep them separate. ${ }^{63}$ A satisfactory solution is found in the Wisconsin adoption statute, under which the termination of parental rights is decided in a separate proceeding and becomes no part of the adoption action. ${ }^{\text {s }}$

Where the consent of the parents is not necessary, somebody else must usually give consent in their stead-the child's legal guardian or next of kin, a "next friend" appointed by the court, or an authorized agency to whom the child has been surrendered. ${ }^{65}$ Little may be gained by permitting

60. 4 Vernier, Adrerican Fasity Laws 340 (1936). Sec, c.g., Idaro Code Asix. \$16-1503 (1948) (consent of spouse required); MLAss. Aws. Laws c. 210, $\$ 1$ (Supp. 1948) (spouse must join in petition). Several of the states requiring joinder male an exception for stepparent adoptions. E.g., TEx. ANn. Crv. Sist. art. 46a, §1 (Vernon, 1947); WISC. STAT. § 322.01 (1947).

61. IEAVY, op. cit. supra note 53 , at 42 .

62. 4 VERNIER, op. cit. supra note 60 , at 341 . As to the consent required when the natural parents are divorced, see Colby, Protection of Children in Adoption, 65 Psoceroings of the Nattonal Conference of Social Work 146, 152 (1939); Note, 91 A.L.R. 1387 (1934).

63. See Note, 14 U. of CHI. L. Rev. 303, 307 n.16 (1947) ; Colby, Protection of Children in Adoption, 65 Proceedings of the National Conference of Soctal Work 146, 152-3 (1939).

64. Wis. Stat. $\$ \$ 322.04(2), 48.07(7)$ a (1947). Following the termination of parental rights the court may, if it chooses, transfer the "care, control and custody" of the child to an authorized agency, which then has authority to consent to the child's adoption. Ibid.

65. The Maine statute is typical in this regard. It provides: "If there are no such parents, or if the parents have abandoned the child and ceased to provide for its support, consent may be given by the legal guardian; if no such guardian, then by the next of lin in the state; if no such kin, then by some person appointed by the judge to act in the proceedings as the next friend of such child. ... In [cases of surrender to an authorized 
a "next friend" to give consent. A Children's Bureau study in 1936 revealed that courts often regarded such appointments as a mere formality. One Rhode Island judge, for example, said that he usually appointed "someone in the room," who merely signed the petition and made no investigation. In Wisconsin the courts usually appointed an attorney, who received a five-dollar fee from the county for his services. ${ }^{66}$ The Alabama-type statute offers a much better solution. It provides that whenever the consent of the parents is unnecessary and the child has no guardian, responsibility for giving consent rests with the state welfare department. ${ }^{67}$

The statutes of many states are inadequate in other respects. A number of them make no provision whereby parents may voluntarily surrender all rights in a child to an authorized agency. ${ }^{68}$ And some states, though permitting surrender, make no provision for dispensing with the consent of the parents in a later adoption proceeding. ${ }^{69}$

There is great diversity among the states as to the form which consent may take. The Utah statute has the most stringent requirement, that all consents must be signed before the court in which the petition is filed. ${ }^{70}$ Other states require that consents be signed before any judge of a court of record, except when the child is legally the ward of an authorized agency.71 In a far greater number of states, however, the sole requirement is that consents be acknowledged before a notary public or other officer authorized to take acknowledgments. ${ }^{72}$ And some states are even more lax: they require simply that consents be "in writing," ${ }^{73}$ or fail to specify any form in which they are to be given. ${ }^{74}$ This laxity may be harmless when an authorized agency is participating in the case. It is dangerous in other circumstances. Natural parents, and particularly unwed mothers, are often pre-

agency or to the state welfare department] the consent to adoption hereinbefore provided for may be given by such incorporated society, asylum, or home, or state department of health and welfare, and the consent of the parents or parent of said child shall not be required." Maine Laws 1945, c. 60.

66. Colby, Problems and Prociedures in Anoption 94-5 (Children's Bureau Publication No. 262, 1941). Such practices still persist in some states today. Essentials of Adoption Law and Procedure 15 (Children's Bureau Publication No. 331, 1949).

67. ALA. Code ANn. tit. 27, $\$ 2$ (1940). North Dakota has a similar provision. N.D. REv. CODE § 14-1104 (1943).

68. E.g., Pennsylvania, South Carolina, Texas.

69. E.g., R.I. Gev. LAws ANN. c. $373, \S 2$ and c. $420, \S 3$ (1938).

70. UTAR Cone ANN. § 14-4-8 (1943).

71. E.g., Mice. Ans. Stat. $\$ 27.3178$ (543) (Supp. 1947) (must be signed before a probate or juvenile court judge); WIs. Stat. \$322.04(4) (1947) (must be signed before a judge of the county in which the parent resides or the child was born); N.D. Laws 1949 , c. $130, \S 1$ (same).

72. E.g., Fla. Stat. ANn. $\$ 72.14$ (Supp. 1948); Maine Laws 1949, c. 173; NEd، Rev. Stat. § 43-106 (1943) ; VA. Code ANN. §63-351 (1950).

73. E.g., Ariz. Code ANN. \$27-203 (1939); N.H. Rev. Laws c. 345, §2 (1942); ORE. COMP. LAWS ANN. $\$ 63.402$ (1940).

74. E.g., Aíla. Cone ANw. tit. 27, §3 (1940); D.C. Code §16-202 (1940); MinN. Stat. Ann. \$259.03 (1947). 
vailed upon to release their children for adoption before they have fully considered the matter, sometimes even before the child is born. To prevent undue influence or precipitate action, an adoption statute should require that all consents be signed in the presence of a judge or a representative of the state welfare department. ${ }^{75}$

\section{Investigation and Trial Period}

In recent years, a highly significant development in the law of adoption is the requirement of a "social investigation" before the court may act upon the petition. The investigation includes an inquiry into the reasons why the natural parents are surrendering their child, into the child's family history, environment, and physical and mental condition, and into the suitability of the prospective adoptive parents to rear the child. In short, it is a codification of the practice of authorized adoption agencies. Today thirty-five states and the District of Columbia make a social investigation mandatory, while six other states provide that it may be made in the discretion of the court. ${ }^{76}$ Approximately two-thirds of these states vest responsibility for making or arranging for the investigation in the state welfare department, or require that it be made by an authorized public or private child-welfare agency." In the remaining states the court may designate a probation officer or other officer of the court, an agency, or "any suitable person" to make the investigation. ${ }^{78}$

The majority practice is clearly superior. Judges have neither the time nor the training to make the investigation themselves. When the matter

75. California requires that consents be signed in the presence of a representative of the state welfare department or of a licensed county adoption agency. This requirement is waived, however, when the adoption is being made by a stepparent or has been arranged through an authorized agency. CAL. CrVIL Cone $\$ 226$ (Deering, 1949).

Courts divide as to whether a natural parent who has given his consent may revolse it before a final decree of adoption has been entered. See Notes, 32 MLwiz. L. REv. 498 (1948); 26 N.C.L. REv. 293, 294-5 (1948); 138 A.L.R. 1038 (1942); 156 A.L.R. 1011 (1945).

76. Colorado, Idaho, Mfississippi, Otlahoma, South Carolina, and Wyoming are the only states which make no provision for a social investigation of any sort. Maine, Maryland, Montana, Nebraska, Nevada, and Pennsylvaniz provide that it may be made in the court's discretion. See, e.g., Mont. Rev. Code § 61-133 (1947) ; Neb. REv. Star. § 43-107 (1943); PA. Stat. Ann. tit. 1, $\$ 3$ (Purdon, Supp. 1948). Oregon leaves the maling of an investigation to the discretion of the state welfare department. ORE Cossp. Laws ANN. \$63-401 (Supp. 1947). Under this provision the welfare department investigates every adoption petition filed in the state except when the placement has been made by an authorized agency. Communication to the YALE LAw Jourana from Mliss Loa Howard, Administrator, Oregon Public Welfare Commission, dated Jan. 1S, 1950, in Yale Law Library. All other states and the District of Columbia make a social investigation mandatory.

77. E.g., DEL. REv. CODE $§ 3550$ (1935); N.MI. Stat. AwN. §25-202 (Supp. 1949); VT. STAT. \$ 9942 (1947).

78. E.g., Irr. ANn. Stat. c. 4, \& 3-1 (Smith-Hurd, Supp. 1949); S.D. Cods $\$ 14.0406$ (1939) ; Wash. Rev. Stat. ANN. §1699-10 (Remington, Supp. 1947). 
is left entirely in their hands, adoption petitions are often filed and granted in a single day. ${ }^{79} \mathrm{It}$ is not enough to require that the investigation be made by somebody other than the judge; reports submitted by attorneys and other persons appointed by the court tend to be inadequate. ${ }^{80}$ The most satisfactory requirement is that all adoption petitions be investigated by caseworkers from the state welfare department or from an agency it designates.

Most states require that once the investigator has submitted his report and recommendation to the court, the court hold a hearing before acting upon the petition. ${ }^{81}$ It is a serious deficiency in many adoption statutes that they make no provision for disposition of the child if the petition is denied..$^{2}$ As a.result, judges often grant an adoption or allow the child to remain in the adoptive home even though they find the placement undesirable. ${ }^{83} \mathrm{An}$ adoption statute should provide specifically that if the petition is denied and the child is not already in the permanent custody of an authorized agency, the judge should certify the case to the court having jurisdiction to determine the custody of children. ${ }^{84}$

About a fourth of the states provide that if the court approves of the adoption, it shall issue an interlocutory rather than a final decree. ${ }^{86}$ There is then a trial period, usually of six months or a year, during which the child

79. A study of 206 adoptions in four Indiana counties in 1939, for example, disclosed that in 150 cases the petition had been granted on the same day it was filed. 7 INDranA Departarent of Public Welfare, Quarterly Statistical Survey 12 (April-June, 1941). The Indiana adoption statute was amended in 1941 to require a social investigation by an authorized agency. IND. STAT. ANN. § 3-118 (Burns, 1946).

80. "When studies are made by social agencies either public or private, complete investigations are made. When made by an attorney or other persons of the Judge's choice, they tend to be meager and incomplete." Communication to the YALE LAW JourNaL from Miss Clara Willman, Supervisor, Children's Services, Washington Department of Social Security, dated Nov. 14, 1949, in Yale Law Library.

81. 4 VERNIER, op. cit. supra note 60, at 296.

82. E.g., Kansas, Montana, Utah.

83. Ostertag Report, supra note 52, at 25-6.

84. For statutory provisions of this type, see, e.g., OHIo GEN. Code ANN. § 10512-21 (Page, Supp. 1949); Fia. Stat. ANn. $\$ 72.28$ (Supp. 1948).

Nineteen states expressly provide for appeal of adoption decrees. Zacharias, Iudicial Review of Adoption Decrees, 23 ChI-KeNt. REv. 233, 237 (1945). For an analysis of the statutes and decisions on this point, see id. at 236-45.

85. LeAvy, op. cit. supra note 53, at 54-6. Several other states make the issurance of an interlocutory decree discretionary with the trial court. E.g., CoNN. GEN. STAT. \& 6867 (1949) ; MD. ANN. Code art. 16, §85J (Flack, Supp. 1947). Furthermore, nearly half the states, although having no provision for an interlocutory decree, require that the child must have lived in the adoptive home for a specified period (usually six months or a year) before the court may approve the adoption petition. LEAvy, op. cil. supra note 53, at 54-6. See, e.g., Neb. Rev. Stat. \$ 43-109(1) (1943) (six months); UTAu CODE ANN. \$14-4-14 (1943) (one year). In these states, however, there is ustally no supervision of the home during this period, unless the placement has been made by an authorized agency. 
lives in the adoptive home. ${ }^{86}$ The person or agency which made the original social investigation visits the child at periodic intervals, and at the end of the period reports its finding to the court. If the court is satisfied that the adoption is in the best interests of the child it issues a final decree. Most of these states give the court discretion to waive the trial period if it sees fit, especially when the placement has been made by an authorized agency. ${ }^{87}$

\section{Placement Statutes}

Placement statutes, which regulate the placing of children in homes in contemplation of adoption, are an adjunct of adoption statutes. An adoption statute, though it embodies all the modern safeguards, including a social investigation as a part of the adoption proceeding, has one main defect: the investigation frequently comes at too late a point. When a child is placed independently the investigation is made only after an adoption petition has been filed, often not until the child has lived in the home for a year or more. ${ }^{83}$ In the meantime, emotional ties have been formed between the child and his new parents-the child has become a part of the adoptive family. Courts are reluctant to break those ties by denying the adoption petition, even though an investigation at this late point may disclose that the placement is unsatisfactory. Judges realize that a child uprooted from one home and transferred to another is subject to considerable trauma. Hence they often think it wiser to approve an unsatisfactory placement rather than to remove a child from the surroundings with which he has become familiar..$^{99}$ In this circumstance the investigatory process has failed to accomplish its purpose.

86. E.g., Ark. Stat. ANn. §56-108 (1947) (six months); FlA. Stat. Axr. \$72.19 (Supp. 1948) (not more than one year as fixed by court); Mircr. Stat. Ax:. $\$ \S 27.3178(546)-(547)$ (Supp. 1949) (one year).

87. E.g., OHIo GeN. Code ANN. $\$ 10512-18$ (Page, Supp. 1949); VA. Code Axs. $\S 63-355(1950)$.

Courts generally hold that an adoption decree may be annulled on the same grounds as any other decree. See Note, 2 A.L.R.2d 887 (1948). But over a third of the states make special statutory provision for annulment of adoptions. The most common formula is that the adoptive parents may seek annulment if the child develops feeblemindedness, insanity, epilepsy, or venereal disease from causes existing at the time of the adoption and not then known to the adopting parents. Broors \& Broors, op. cit. supra note 16, at 132. See, e.g., Iowa Code $\$ 600.7$ (1946); UTAr Code ANw. $\$ 14-13$ (1943).

88. Many states provide that the child must have lived in the prospective adoptive home for a period of six months or a year before the adoption may be approved by the court. See note 85 sipra. And in many cases an adoption petition is not filed until the child has lived in the home for a period exceeding the statutory minimum. Lulas, Babies Are Neither Vendible Nor Expendable, 5 N.Y. CrTY Bar Ass': Recono 104 (1950) ; Townsend, Placentent and Protcctive Sercices in Adoption, 75 Procezonizes of tine National Conference of Socral Work 331, 334 (1949).

89. Ostertag Report, supra note 52, at 25; Colby, Protection of Children in Adostion, 65 Prockedings of the National Conference of Soctal Work 146, 154 (1939); Seeley, Adoptions: Maryland's Better Way, 37 Surver Grapurc 255, 258 (1948). 
Legislatures have sought to plug this hole by enacting three types of placement statutes: those outlawing independent placements, in whole or in part; those requiring judicial or administrative approval before an independent placement may be made; and those authorizing administrative investigation once a child has been placed independently. The results are not encouraging.

The statutes of eleven jurisdictions provide that no person except a natural parent, a guardian, a relative, or an authorized agency may place a child in a home in contemplation of adoption..$^{90}$ These statutes have proved almost completely ineffective. The exception made for natural parents opens the door to all types of independent placements. Evasion of the statute is simple; a third party who arranges a placement can easily make it appear that the placement was made directly by the natural mother. ${ }^{11}$

90. Alabama, California, District of Columbia, Montana, New York, North Dakata, Oregon, South Dakota, Texas, Virginia, and Wisconsin. See, e.g., CAI. Crv. Code $\$ 224 \mathrm{q}$ (Deering, 1949) (parents and authorized agencies); N.Y. SOCTAL WeLfare LAW \$374(2) (parents, guardians, second degree relatives, and authorized agencies); D.C. CoDE $\$ 32-785$ (Supp. 1949) (parents, guardians, third degree relatives, and authorized agencies).

91. The reluctance of law-enforcement officials to prosecute under a statute of this type is well illustrated by a recent opinion of the attorney-general of Wisconsin. The Wisconsin statutes provide that "no person, other than the parent or legal guardian, and no firm, association or corporation, and no private institution shall place, assist, or arrange for the placement of any child in the control and care of any person, with or without contract or agreement, or place such child for adoption, other than a licensed child welfare agency"; and that "no person conducting or in any way connected with the conduct of any maternity hospital shall in any way directly or indirectly offer to dispose of any child or hold himself out as being able to dispose of children in any manner." Wis. Stat. $\$ \$ 48.37(1), 48.45(1)$ (1947) (emphasis added). In an opinion addressed to the director of the state welfare department, dated July 24,1948 , the attorney-gencral of Wisconsin spoke as follows: "You have submitted a number of types of cases of irregular placements and inquire in each case whether the facts show a violation of one or the other of the above statutes.

"A. The physician who confined Miss A, an un-married mother, learned that she had expressed a wish to place her child for adoption. He therefore informed $\mathrm{Mr}$. and Mrs. Y, who were patients of his, that he knew of a child that would be available for adoption. He gave the name of the adoptive parents to the mother. They made arrangements to transfer the child to them upon discharge from the hospital. The adoptivc parents sent a relative to meet the mother outside the hospital and the relative transported the child alone to the prospective adoptive home.

" $\mathrm{B}$. The physician who confined Miss B, an unmarried mother, learned that she had expressed a desire to place her child for adoption. The physician told the mother that he knew a desirable adoptive home. He communicated with the proposed adoptive family, telling them about the child and suggesting that they employ an attorney. Subscquently, the attorney visited the mother and obtained the mother's consent. Upon discharge from the hospital the mother and child were met by the adoptive parents who took the child to their home.

“...

"In case $A$ it is our opinion that on the narrow fact situation presented no stuccessful prosecution could be maintained. While it could be argued that one who gives information gratuitously to the parties performs a material act of 'assistance,' it is our view that unless 
But the statutes of eight states are apparently much more rigid, and prohibit all independent placements except when made with relatives.02 In two of these states-Utah and New Jersey-the attorney-general has nullified the statute by ruling that it does not apply to natural parents..3 The statutes of the other states, though purporting to require that all placements with non-relatives be made through authorized agencies, have been notably unsuccessful. In Indiana, for example, over half of all placements are made independently; in Maine independent placements accounted for 91 percent of the total in $1948 . .^{94}$ Officials are loath to prosecute when authorized agencies are already heavily overburdened.

A few states have sought to control independent placements by requiring approval of the welfare department or a court order before a child is placed in a home in contemplation of adoption. ${ }^{95}$ Those statutes which require a court order make no provision for an investigation before the order is issued..$^{96}$ But this is a minor problem compared with the extent to which the statutes are disregarded entirely. The Ohio law, for example, provides that no placement of a child under two years of age may be made

more could be shown it would be impossible to obtain a conviction. If the physician, in addition to informing the prospective adoptive parents of the existence of the child, actively promoted the placement, there would be a clear violation. But just passing on the information is insufficient in our judgment to warrant a prosecution. The doctor could always say that nothing he did prevented the parties from using proper channels in obtaining the placement. Nor was the act of the relatives in taking possession of the child for the adoptive parents, after the arrangements had been made, sufficient in our judgment to warrant prosecution.

"In case B it is also our view that the physician should not be prosecuted for merely" giving the information, particularly since he suggested employment of an attorney. The attorney, according to the facts stated, merely performed a legal service in obtaining the mother's consent and did not 'assist' in or 'arrange' for the placement in the sense meant by the statute." 37 OpINions of THE AtToRNEy GenernL of Wiscosisis 403, 405-7 (1948).

92. Colorado, Georgia, Indiana, Iowa, Maine, New Jersey, Tennessee, and Utah. See, e.g., Tenn. Acts 1949, c. 127, \$11 (no exceptions); GA. Asv. Copg \$99-201 (1937) (second degree relatives); Iowa CoDE $\$ 238.25$ (1946) (fourth degree relatives).

93. Communication to the YaIE LAw Jourival from Mrr. John F. Larson, Director, Bureau of Services for Children, Utah Department of Public Weliare, dated Nov. 15, 1948, in Yale Law Library; Communication to Mrr. Sanford Bates, Commissioner, New: Jersey Department of Institutions and Agencies, from Mr. Walter D. Van Riper, Attorney-General of New Jersey, dated Aug. 14, 1946, photostatic copy in Yale Law Library. A recent New Jersey decision confirmed the attorney-general's ruling. In re Mrofiett, 5 N.J. Super. 82, 68 A.2d 479 (1949).

94. Communications to the Yale Law Journal from Mfr. E. Mr. Dill, Administrator, Indiana Department of Public Welfare, dated Dec. 5, 1949, and from Mfiss Lena Parrott, Director of Child Welfare, Maine Department of Health and Welfare, dated Nov. 14, 1949, both in Yale Law Library.

95. E.g., Mich. Stat. ANw. $\$ 27.3178(552)$ (Supp. 1949) (court order); Mo. Rev. Stat. Ann. $\$ 9616$ (Supp. 1949) (court order); Neb. Laws 1949, c. 204, \$1 (court order); OHIo Gen. Code Awn. \$1352-13 (Page, 1946) (consent of welfare department or court order for children under two years).

96. Except for Michigan. 
without written consent of the state welfare department or commitment by a juvenile court. A study of adoption practices in sixty-one Ohio counties in 1938 disclosed widespread violation of this provision by parents, doctors, nurses, maternity homes, lawyers, authorized agencies, and even by juvenile courts which did not have proper jurisdiction over some of the children whom they had placed. ${ }^{97}$ Yet there have been few prosecutions for violation of the statute..$^{98}$

Four states require that whenever a child is placed independently for adoptive purposes, either the person who places the child or the person who receives the child must notify the state welfare department. 92 The department is given authority to investigate the case and, if it finds that the child has been placed in an unsuitable home, to take the child into its custody. But in three of these states the investigation is discretionary with the department, ${ }^{100}$ and in the one state which makess an investigation mandatory, the present case-load is over 200 investigations per caseworker. ${ }^{101}$

Evidently, a state cannot rid itself of independent placements by outlawing them. The ultimate answer to the problem may be a requirement that all placements be made through authorized agencies, which would be given enough money and large enough staffs to handle the additional load. At present, however, no state seems ready to put up the necessary funds.

Meanwhile, probably the most satisfactory check on independent placements would be to pass and enforce a statute providing that every person who receives a child into his home and intends to provide it with permanent care must register with the state welfare department. The registrant should be required to file a report setting forth facts about the child, the natural parents, and the manner in which the child was obtained. An investigation by the welfare department should be mandatory. The department, if it regards the placement as unsuitable, should be authorized to apply for a court order terminating it. There should be subsequent investigations until the child is formally adopted or reaches the age of sixteen. ${ }^{102}$

97. Mulinnsix, OHio Adoption Study 28-30, 38-9, 42, 178 (mimeographed, 1941).

98. Id. at 144; Communication to the Yale LAw Journal from Judge J. H. Lanneck, Director, Ohio Department of Public Welfare, dated Nov. 22, 1949, in Yale Law Library.

99. MD. Ans. Code art. 88A, §16H (Flack, Supp. 1947) (receivers must notify welfare department); MASs. ANs. LAws c. 119, $\$ 14$ (Supp. 1948) (placers and receivers) ; N.H. REv. LAws c. $130, \S \$ 17-8$ (1942) (receivers); R.I. GEN. LAws ANN. c. $373, \S 3$ (1938) (placers). Kentucky provides that any person who places a child for adoption without first notifying the welfare department and obtaining its consent is guilty of contributing to the neglect of the child. Ky. REv. STAT. $\$ 405.370$ (1948).

100. Massachusetts, Maryland, and New Hampshire.

101. Communication to the Yale Law Journal from Mr. Lawrence C. Cole, Administrator, Children's Division, Rhode Island Department of Social Welfare, dated Nov. 22, 1949, in Yale Law Library.

102. Various civic organizations in New York, including the Society for the Prevention of Crime and the New York City Committee on Adoptions, are secking enactment in that state of a bill with substantially these provisions. N. Y. State Assembly, Bill No. 2347, introduced by Assemblyman Rabin, Feb. 22, 1949. The bill failed of passage at the 
A registration scheme of this sort would involve substantial outlays. But being less complete, it would cost much less than a program requiring that all placements be made through authorized agencies. Since a child would go directly from his former home to his adoptive home, an agency would not have the expense of supporting him for a period of a few months to several years. Investigation of the adoptive parents and of the child would be less complete, and therefore less expensive, than if an agency had arranged the placement. Adoptive parents rather than the agency could pay the doctor's fee and hospital expenses of the natural mother.

In addition to passing registration statutes, states should promptly outlaw independent placements in which a third party makes a profit. The New York legislature recently enacted such a statute, making it a misdemeanor for the first offense and a felony for subsequent offenses to give or receive compensation for placing out a child. ${ }^{103}$ The statute specifically exempts payments to authorized agencies and payments by adoptive parents to cover the "reasonable and actual" medical fees and hospital expenses of the natural mother.

\section{LONG-RUN REFORA}

Registration and anti-profiteering laws would be improvements but not cures. The basic difficulty in the field of adoption is a shortage of applied community resources. Additional facilities are required not only for the placement of children in adoptive homes, but for the care of unmarried mothers as well. Case work service, financial assistance, and medical and confinement care are essential. ${ }^{104}$ Yet at present community services for the unmarried mother are inadequate in the extreme. Her problem is particularly acute if she has left her home town; often her care cannot be financed from public funds because of legal limitations on residence, and private funds are not available because private agencies give preference to local applicants. ${ }^{105}$ As long as the community ignores her needs she will continue to place her child through unauthorized sources or, far worse, resort to abortion to keep from having the child at all. An adequate program of assist-

1949 session of the legislature, but renewed efforts are being made to secure its passage at the current session.

103. N.Y. PENAL LAw \$ 487-a. The first information under this statute was returned on Dec. 5, 1949, against Irwin Slater, a New York attorney. N.Y. Times, Dec. 6, 1949, p. 38 , col. 6.

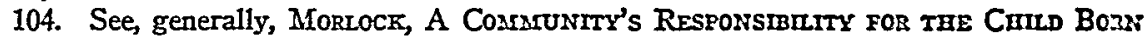
Out of Wedrock (mimeographed, 1949); Mforlock \& Casrperle, Mlateraits Houres for UnMrarried Motelers (Children's Bureau Publication No. 309, 1946); Brenner, What Facilities Are Essential to the Adequate Care of the Unmarried Afother?, 69 Proceennics of the Natronal Conference of Soctal Work 426 (1942); Brower, What Shall I Do With My Baby?, 12 C표 166 (1948).

105. Indiana Departarent of Public Welfare, Sumarary Refort of Adopmoz: and UnMarried Mother Study 7 (mimeographed, 1946); Nev Yore City CornstrteE on Adoptions, Adoption in New York Crty 11-12, 33-4 (194S); Ostertag Repozt, sippo note 52, at 55-7. 
ance would avert unsatisfactory adoptions, increase the supply of children for deserving persons to adopt, and relieve the underworld abortionist of most of his business.

Adoption agencies themselves are partially to blame for the fact that three out of every four adoptions are independently arranged. Some agencies have too rigid a notion of what constitutes an adoptable child. ${ }^{100}$ At times an overly cautious attitude leads them to pass up valuable placement opportunities. ${ }^{107} \mathrm{~A}$ few agencies still disqualify adoptive applicants on a superficial basis. ${ }^{108}$ But these practices are not typical. One of the most encouraging signs at present is the extent to which agencies are moving toward more flexible standards.

Generally, agencies have the will but they do not have the way. Most of them are supported entirely by private funds; in only a few cities, such as Chicago, Cincinnati, and New York, are part of their expenses paid by the city government. ${ }^{109}$ In an effort to increase their facilities, agencies are experimenting with the practice of charging fees to adoptive parents. ${ }^{110}$ But this will always be a limited source of private funds if adoptive applicants are to be chosen on the basis of their qualifications as parents and not on the basis of their incomes. Hand in hand with an expansion of private facilities there must be an expansion of public facilities as well. State welfare departments, financed by state funds and federal Social Security grants, ${ }^{111}$ make few direct placements and of ten lack the personnel to investigate independent placements.

The need for sound adoption practices is great and is steadily increasing. It is time the states moved to meet it.

106. MulzinNix, op. cit. supra note 97, at 114, 185; Ostertag Report, supra note 52, at 58; Johnson, Why Babies Are Bootlegged, 77 SURvey 176 (1941).

107. Theis, Case Work in the Process of Adoption, 69 Procendings of the Natronat CONFERENCE OF SOCIAL WORK 405, 408-9 (1942).

108. See page 721 supra.

109. Brooks \& Brooks, op. cit. stipra note 16, at 113; New York City CoMnIITter on Adoptions, op. cit. stpra note 105, at 18; Polier, Everyone's Children, NoBody's Child 216 (1941).

110. Some agencies charge a flat fee, often of $\$ 100$ or $\$ 150$. See Carlton, An Adoption Agency Looks at Fees, 23 Child Welfare League of America Bulletin 4 (Feb. 1944) ; Foster, Fees for Adoption Service, 74 Procendings of the National Conference OF SOCIAL WORK 344 (1948). A number of agencies, however, have a graduated scalc geared to the income of the adoptive family. The Spence-Chapin Adoption Service of New York City, for example, charges adoptive parents a fee of $\$ 100$ to $\$ 450$, depending on their circumstances. Spence-Chapin Adoption Service, 1948 AnNual Report (1949). The Free Synagogue Child Adoption Committee of New York City recently established a schedule ranging from a $\$ 200$ fee for incomes below $\$ 3,500$, to a $\$ 1200$ fee for incomes above $\$ 15,000$. N.Y. Times, Jan. 10, 1950, p. 37, col. 5 .

111. The Social Security Act of 1935 authorized an annual appropriation of $\$ 1,510,000$ to be alloted to the states for the development of child-welfare services. 49 STAT. 633 (1935), 42 U.S.C. $\$ 721$ (1946). In 1946 Congress increased the authorized annual appropriation to $\$ 3,500,000$. 60 STAT. 986 (1946), 42 U.S.C. $\$ 721$ (1946). The allotment is made, by the Federal Security Administrator on the basis of plans developed jointly by" him and state welfare departments. Ibid. 